\title{
Pelas ruas, de porta em porta. Verdureiros, quitandeiras e o comércio ambulante de alimentos em Campinas na passagem do Império à República
}

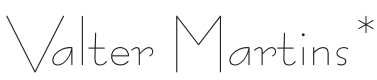

Introdução

Nas últimas décadas do século XIX e início do XX, a cidade de Campinas passou por importantes transformações: urbanas, econômicas, sociais. Sua população cresceu com a expansão da cafeicultura que atraiu nacionais e imigrantes em busca de oportunidades de trabalho. Ao mesmo tempo, recebeu muitos escravos oriundos do tráfico interprovincial. A cidade chegou a ostentar o título de "Capital Agrícola da Província", embalando o sonho de muitos campineiros em torná-la capital de São Paulo.

Lucros, acumulados com a exportação cafeeira e investidos localmente, proporcionaram um aparelhamento urbano dos mais sofisticados no Brasil daqueles tempos.

Desde 1861, Campinas possuía um Mercado Municipal para abastecer seus habitantes com gêneros de primeira necessidade. A chegada da Ferrovia Paulista ligando Campinas a São Paulo e Santos, em 1872, marcou uma nova fase no desenvolvimento da região. A vida social tomou novo impulso e, para os contemporâneos, ganhou "uma feição mais civilizada". A cidade crescia e se renovava e os caminhos desse processo por vezes eram tortuosos.

* Professor adjunto na Universidade Estadual do Centro-Oeste UNICENTRO Campus de Irati/PR. Doutor em História Social pela USP. 
Fazendo parte dos "tempos civilizados", no ano de 1872, junto com a ferrovia, a cidade ganhou também seu primeiro Mercado de Hortaliças, obra da Câmara Municipal. ${ }^{1}$

Em 1875, as noites das principais ruas do centro da cidade foram iluminadas por lampiões a gás. Para o então recém-fundado Diário de Campinas, aquele melhoramento colocou fim "ao tempo do viver galináceo em Campinas". ${ }^{2}$

Entre 1876 e 1879, muitas novidades, visando atender às necessidades do tempo que "acelerava": Santa Casa de Misericórdia, Asilo de Morféticos, Hospital da Beneficência Portuguesa, Companhia de Carris de Ferro Campineira, Clube da Lavoura, Escola Corrêa de Mello, Passeio Público, Hipódromo, Rink Campineiro e o Templo da Igreja Presbiteriana.

A cidade tornava-se cada vez mais "equipada" e em sintonia com as inovações que chegavam de "Maria-Fumaça". Instituições de cura e de ensino, novas opções de lazer e serviços, então privilégios da Corte e capitais de província, passaram a fazer parte do cotidiano campineiro. Além de iluminação, as ruas centrais ganharam calçamento. Carroças e carruagens misturavam-se aos bondes do transporte coletivo, movidos por tração animal. O "novo tempo" entusiasmava os articulistas dos jornais:

O caráter fisiológico, se assim se pode dizer da nossa sociedade, atesta que a civilização, não se impondo com a brutalidade de um fato absolutamente imprescindivel, mas, chegando-se a pouco e pouco, segundo o crescimento das diversas necessidades, encontrou aqui o melhor campo para firmar-se em solidíssimas bases (...) Há então, como que uma sede de ir adiante, à busca de novas idéias, de esclarecimentos novos e pela lei da perfectibilidade sentimo-nos impelidos, na frase

\footnotetext{
${ }^{1} \mathrm{O}$ primeiro mercado da cidade foi concluído em 1861 . Com a construção do Mercado de Hortaliças, em 1872, aquele ficou conhecido como Mercado Grande e o de Hortaliças, como Mercadinho. Em 1885, o Mercado de Hortaliças foi demolido enquanto era construído o segundo Mercado de Hortaliças, inaugurado em dezembro de 1886

${ }^{2}$ Diário de Campinas, 21/11/1875, n. ${ }^{\circ}$ 54, p. 2. 
de um escritor, para a senda ascendente do belo, do verdadeiro, do útil, que é a da civilização. ${ }^{3}$

A fixação da elite agrária nas cidades motivou seu crescimento e a formação de uma estrutura de melhoramentos e facilidades urbanas que começou a atrair cada vez mais mão de obra e investimentos. Essas mudanças aconteceram associadas a um novo modo de pensar e viver a cidade, cada vez mais influenciado pelas normas sanitárias. ${ }^{4}$

Em meio a tantos avanços, a população continuava a beber água dos velhos chafarizes. Imprescindiveis para o abastecimento de uma cidade que não contava com rede de distribuição domiciliar, eram frequentados por escravos, pelas barulhentas lavadeiras e outros membros das "classes populares". A Companhia Campineira de Águas e Esgotos foi fundada em 1887, mas a cidade conheceria o conforto da água encanada somente na década seguinte, após as epidemias de febre amarela. Aos poucos, a expansão da rede de água urbana faria desaparecer os pitorescos e animados chafarizes. Para Michelle Perrot, tais locais eram importantes para o trabalho e a sociabilidade feminina. Para as autoridades municipais, eram lugares que concentravam problemas. ${ }^{5}$

A "produção" da cidade e a ocupação de seu espaço passaram a ter regras mais detalhadas em relação aos Códigos de Posturas Municipais anteriores ao de 1880. Quando editado o Código de 1880, predominavam ainda as construções feitas em taipa, reminiscências dos tempos coloniais que, aos poucos, cederam seus terrenos para as "construções modernas". As casas que a partir de então se

$\overline{{ }^{3} \text { Diário de Campinas, 01/01/1880, n. }{ }^{\circ} 1260 \text {, p. } 2 .}$

${ }^{4}$ LANNA, Ana Lúcia Duarte. Uma cidade na transição. Santos: 1870-1913. São Paulo: HUCITEC, 1996, p. 15-16.

${ }^{5}$ PERROT, Michelle. Os excluídos da História. $4^{\mathrm{a}}$ ed. Rio de Janeiro: Paz e Terra, 2006, p. 202-204. Em 1885, o vereador Ricardo Gumbleton Daunt pediu providências à Câmara para "prevenir os conflitos que se dão nos chafarizes entre os carroceiros, vendedores de água e outras pessoas do povo". Tais conflitos se agravavam em tempos de seca quando o volume de água nos chafarizes diminuía. Atas da Câmara Municipal de Campinas, daqui por diante ACMC, 20/03/1885; ACMC, 04/11/1885. 
construíssem, muitas delas assimilando a nova arquitetura que se difundia, seriam erguidas (pelo menos em princípio) respeitando as prescrições da Câmara. ${ }^{6}$

As edificações em Campinas não passaram apenas por mudanças estéticas e quanto às suas dimensões padronizadas. Aquelas conhecidas então como "modernas" estavam diretamente associadas a um tipo de material: o tijolo. ${ }^{7}$ Ao retornar da Bélgica, em 1879, o engenheiro-arquiteto Francisco de Paula Ramos de Azevedo contribuiu com seus projetos para a difusão do tijolo como material de construção substituindo as taipas barrocas, símbolo do passado colonial que se desejava superar.

Nas décadas finais do século XIX e iniciais do XX, as ruas de Campinas, a exemplo de tantas cidades brasileiras, tiveram seus leitos revolvidos para instalação de tubos pelos quais circulariam fluidos variados: gás, água potável, esgotos. As ruas passaram a ter também uma função subterrânea, melhorando as condições de salubridade. Essas "maquinarias urbanas", como as chamou François Béguin, não ficaram restritas ao subsolo. Constituíram verdadeira intervenção na vida cotidiana e doméstica das pessoas que passaram a usufruir daquelas facilidades. Para Béguin, o conforto é uma disciplina suave, que produz efeitos que escapam à maioria das pessoas. Assim, combustores de gás, torneiras, ralos e vasos sanitários, extremidades de um sistema complexo que aos poucos ganhou o interior das casas, estabeleceram melhorias sedutoras e irresistiveis por seu caráter benéfico. O preço? Pessoas cada vez mais isoladas e fechadas em suas moradias. Canos levando água aos domicílios representaram o progressivo fim das conversas e sociabilidades (subversivas?) em torno aos chafarizes. ${ }^{8}$

\footnotetext{
${ }^{6}$ Código de Posturas de Campinas de 1880, artigos de 1 a 23.

7 Gazeta de Campinas, 13/11/1873, n. ${ }^{\circ}$ 408, p.3; Gazeta de Campinas, 09/11/1875, n. ${ }^{\circ}$ 605, p.4; Diário de Campinas, 13/11/1880, n. ${ }^{\circ} 1512$, p.3; Diário de Campinas, 16/11/1880, n. ${ }^{\circ} 1514$, p.2. O Almanak da Província de São Paulo para 1873, São Paulo: Typographia Americana, 1873, p.346, apresenta uma lista de 13 olarias funcionando em Campinas naquele momento.

8 BÉGUIN, François. Les machineries anglaises du confort. Recherches, Fontenay-sous-Bois: n. ${ }^{\circ}$ 29, p. 155-186, 1978. Sobre a implantação do serviço de água 
A fisionomia da cidade passou por várias transformações e cada vez mais as intervenções em seu espaço eram dirigidas, ao menos nas intenções de seus dirigentes, por normas técnicas. O engenheiro Ramos de Azevedo prestava serviços à Câmara Municipal de Campinas e a necessidade de várias obras públicas motivou Azevedo e seu colega Samuel Malfatti a apresentarem uma proposta à Câmara para ampliação do perímetro urbano e um projeto geral para o nivelamento das ruas e praças, no qual indicavam os encanamentos de gás e a localização dos combustores. A cidade ganhou um "mapa" daquilo que havia sob seus pés. ${ }^{9}$

Em janeiro de 1885, Ramos de Azevedo e Luís Augusto Pinto esboçaram um projeto de Posturas Municipais. Mesmo incompleto em vários de seus itens, suas 35 páginas versavam sobre a reorganização do espaço da cidade, normas para construções, calçamento de passeios e criação de um padrão municipal para construção de fossas para latrinas. As escavações, o escoamento das águas pluviais, a instalação da rede de água e esgotos, a conservação de edificios, ruas, praças, arborização e "aformoseamento" foram alvos das atenções dos engenheiros. A cidade seria dividida em três perimetros concêntricos que poderiam ser ampliados em caso de necessidade: $1^{\circ}$ - perímetro do comércio, $2^{\circ}$ - perímetro médio, $3^{\circ}$ - perímetro dos arrabaldes. Sobre o primeiro perímetro, o central, recaíam várias exigências estéticas e relacionadas às medidas dos imóveis e materiais de construção que deveriam ser utilizados. Caso cumpridas, funcionariam como eficazes meios de exclusão social. O perímetro comercial deveria ser reservado à elite, uma vez que ali os cortiços seriam proibidos. No segundo perímetro ficariam localizadas as habitações populares e, no terceiro, as fábricas e oficinas que produziam poluição do ar, das águas e sonora. ${ }^{10}$

e esgotos em Campinas veja: LAPA, José Roberto do Amaral. A cidade. Os cantos e os antros. São Paulo: EDUSP, 1996, p. 295-307.

${ }^{9}$ Atas da Câmara Municipal de Campinas, 10/03/1884; ACMC, 20/03/1884; ACMC, 31/03/1884; ACMC, 10/10/1884.

${ }^{10}$ Arq.CMC, cx. C1/4, pasta 1885/II, Projeto de Posturas: Ramos de Azevedo e Luis Pinto, 09/01/1885, especialmente p. 1, 2, 3, 5, 6, 10, 12, 13, 14, 18, 23 e 25. Entre as páginas 18 e 20 , o projeto apresenta suas normas para a constru- 
Para Raquel Rolnik, as normas urbanísticas buscavam moldar a cidade ideal, desejável. Ao estabelecer o proibido e o permitido, tais normas buscavam definir territórios dentro ou fora da lei, de plena cidadania e de cidadania limitada. Isso, no entanto, nem sempre ocorria da maneira esperada. ${ }^{11}$

Ainda em 1885, Ramos de Azevedo elaborou o projeto e acompanhou a construção do novo matadouro da cidade. Mais que autor do projeto, Azevedo era um dos sócios no empreendimento, ao lado de Francisco Glicério e Bento Quirino dos Santos. O espaço da cidade em mutação revelava-se um ótimo negócio, oferecendo oportunidades aos que desejavam investir em seu aparelhamento e em sua renovação e também àqueles que, desprovidos de capital, buscavam melhores chances de trabalho e de vida. ${ }^{12}$

Carroceiros e cavaleiros que sempre haviam utilizado as ruas livremente, nos dois sentidos, passaram a conviver com as primeiras ruas de mão única. A mudança buscava ordenar a grande circulação de carros, carroças e outros veículos em direção à estação da Ferrovia Paulista. ${ }^{131} \mathrm{Em} 1892$, o fiscal municipal pedia que, para irem à estação, os carroceiros o fizessem pela Rua Bom Jesus, retornando ao centro pela Rua Dr. Costa Aguiar, deixando a Rua Treze de Maio somente para o trânsito dos bondes, "a fim de serem evitados desastres e incômodos para os passageiros". ${ }^{14}$

Em 1883, a Câmara Municipal tomou conhecimento do interesse dos empresários Antonio Pinto da Silva e Ferdinand Rodde em estabelecer o serviço telefônico em Campinas. Rodde desejava ligar por telefone Campinas a São Paulo e San-

\footnotetext{
ção de cortiços. As ideias contidas no inacabado projeto de Ramos de Azevedo Luís Pinto não foram implementadas. Entretanto, o projeto deixou sua marca na legislação urbana através da exigência, por parte da Câmara Municipal, de esboços prévios das edificações para serem aprovadas ou não por seu engenheiro. Exigência muitas vezes descumprida.

${ }^{11}$ ROLNIK, Raquel. A cidade e a lei. Legislação, política urbana e territórios na cidade de São Paulo. São Paulo: Studio Nobel/FAPESP, 1997, p. 13-14

${ }^{12}$ ACMC, 30/09/1886.

${ }^{13} \mathrm{ACMC}, 19 / 05 / 1873$.

${ }^{14}$ ACMC, $10 / 10 / 1892$. 
tos, afirmando que "tais cidades não devem estar por mais tempo privadas de tão importante melhoramento". ${ }^{15}$

O telefone rapidamente incorporou-se à vida da cidade e de muitas fazendas. A Empresa Telefônica Campineira e a Companhia de Telégrafos Urbanos disputavam assinantes fazendo propaganda nos jornais. A primeira lista telefônica de Campinas contava 56 assinantes, incluindo hospitais, médicos, Companhia do Gás, Companhia de Carris de Ferro, hotéis, jornais, lojas, armazéns de secos e molhados, barbeiros, farmácias, advogados e residências. ${ }^{16}$

Para ampliarem seus negócios, várias fábricas instalaram seus telefones como a fundição da Viúva Faber \& Filho, a fábrica de águas gasosas de E. Bolidair \& Comp., a fábrica de cerveja de Carlos Böemer e a Lidgerwood \& Comp. ${ }^{17}$

As fábricas aumentaram em número e se diversificaram. Algumas delas iniciaram suas atividades na década de 1850, como a fábrica de carros e carroças de Francisco Krug, fundada em 1852, ou a Fundição Arens, de $1858 .{ }^{18}$

O Código de Posturas Municipais de 1876 proibiu as fábricas que poluiam o ar, os córregos e produziam muito ruído de permanecerem dentro do perímetro urbano, buscando preservar a salubridade e o sossego públicos. Como esse Código acabou rejeitado pela população, essas medidas foram adiadas e as chaminés, os apitos, os ruídos das máquinas a vapor e os operários, tornaram-se familiares aos campineiros mesmo com escravos ainda circulando pelas ruas. ${ }^{19}$

Com as fábricas surgiram as primeiras organizações operárias. Os ferroviários das Companhias Paulista e Mogiana organizaram a Associação de Auxílios Mútuos, em 1884.

\footnotetext{
${ }^{15}$ ACMC, 01/10/1883.

16 Gazeta de Campinas, 16/01/1884, n. ${ }^{\circ}$ 2995, p.3; Diário de Campinas, 04/04/1884, n. ${ }^{\circ}$ 2504, p.3.

${ }^{17}$ Diário de Campinas, 04/04/1884, n. ${ }^{\circ} 2504$, p.3.

${ }^{18}$ Gazeta de Campinas, 03/05/1877, n. ${ }^{\circ} 1024$, p.4; Arq.CMC, cx. C6/7, pasta 1890, 19/07/1890. Veja também: CAMILLO, Ema Elisabete Rodrigues. Guia histórico da indústria nascente em Campinas: 1850/1887. Campinas: Mercado das Letras, 1998.

${ }^{19}$ Código de Posturas Municipais de Campinas de 1876, artigos 292 a 294.
} 
Em 1887, foi organizada a Liga Operária Cosmopolita que, segundo Alberto Sarmento do Diário de Campinas, tinha como metas principais o mútuo acordo entre os patrões e operários tendo em vista harmonizar os interesses do capital e do trabalho. Dessa maneira, esperava-se que as greves fossem evitadas. E realmente foram poucas. ${ }^{20}$

No final da última década do século XIX, após sucessivas epidemias de febre amarela, Campinas ressurgiu como Fênix de suas próprias cinzas para o século XX retomando seu desenvolvimento. Para as classes populares, o novo século trouxe poucas mudanças quanto às dificuldades diárias de sobrevivência. Muita gente que sempre havia atuado como vendedor ambulante, especialmente de alimentos, continuou no ramo. Era uma das possibilidades acessiveis, mesmo cheia de percalços, para ganhar o pão de cada dia em um mercado de trabalho em formação. Para aqueles homens e mulheres, imprescindiveis para a regular oferta e distribuição de alimentos, as transformações na organização do espaço e do cotidiano urbano balizaram as suas próprias vidas. Com suas vidas, imprimiram suas marcas na cidade.

\section{O comércio ambulante de alimentos}

Quando alguém precisava de verduras, legumes, um pedaço de carne para o almoço, fruta ou doce para sobremesa poderia conseguir aqueles itens sem sair de casa. Muitos vendedores ambulantes percorriam as ruas de Campinas apregoando os mais variados gêneros alimentícios. Se as pessoas não iam ao mercado, o mercado chegava até elas em tabuleiros, carrinhos de mão, cestos e carroças, conduzidos por livres e escravos, brasileiros e imigrantes, entre eles, muitas mulheres.

Verdureiros, quitandeiras, vendedores de carnes, miúdos, aves, queijos, linguiças, peixes, leite, entre tantos outros produtos, participavam ativamente no abastecimento

20 Correio de Campinas, 05/08/1885, n. ${ }^{\circ} 175$, p.1; Diário de Campinas, 19/10/1887, n. ${ }^{\circ} 3558$, p. 1 . 
de alimentos, constituindo, ao lado dos mercados, vendas e armazéns, um importante elo entre os agricultores no campo e os consumidores na cidade. Consigo levavam sons, cores, sabores e aromas que ajudavam a movimentar e temperar o dia a dia. Circulando por todos os cantos, conhecendo muito bem a geografia da cidade, os ambulantes eram os verdadeiros "donos das ruas". Tanta mobilidade e liberdade preocupavam as autoridades municipais que tentavam controlar sua atividade. Para exercerem seu oficio deviam pagar uma licença anual. Estavam sujeitos às normas estabelecidas nas Posturas Municipais e eram acompanhados de perto pelo fiscal, não raro, pela polícia.

O trabalho dos ambulantes estava bastante ligado ao Mercado de Hortaliças. Seu regulamento, de 1886, determinava que, antes de começarem suas vendas pelas ruas da cidade, deveriam permanecer naquele local até às 10 horas, a fim de ser verificada a salubridade dos alimentos pelo inspetor do mercado e também atender aos consumidores que para lá se dirigiam pela manhã. Muitos vendiam gêneros produzidos por eles mesmos como Agostinho Francisco, arrendatário da chácara São João e os alemães do bairro rural de Friburgo. ${ }^{21} \mathrm{~A}$ maioria dos ambulantes, no entanto, funcionava como intermediária entre os pequenos agricultores e chacareiros e seus fregueses, comprando suas mercadorias diretamente na roça ou nos mercados. Muitas mulheres garantiam sua humilde existência na cidade através daquele pequeno comércio "a retalho". Muitas vezes, para conseguirem gêneros para vender, acabavam por representar o papel de atravessadoras. Em 1873, várias foram as reclamações encaminhadas à Câmara Municipal contra as verdureiras e quitandeiras. Costumavam ir ao Mercado de Hortaliças de madrugada e compravam todas as verduras assim que os sitiantes chegavam com suas carroças, revendendo-as pelo dobro do preço no próprio mercado e pelas ruas.

${ }^{21}$ Regulamento do Mercado de Hortaliças de 1886 , artigo $1^{\circ}, \S 1^{\circ}$; Arquivo Público e Histórico de Campinas, (daqui por diante APHC) cx. 1904/02, pasta julho, 06/07/1904; Diário de Campinas, 05/09/1879, n. ${ }^{\circ} 1163$, p.2; Diário de Campinas, $03 / 01 / 1880$, n. $^{\circ} 1261$, p.3. 
A intensificação da urbanização e da imigração com o avanço da economia cafeeira introduziu novos hábitos e criou novas possibilidades aos habitantes da cidade. Vender frangos e galinhas de porta em porta tornou-se uma atividade bastante comum, especialmente entre imigrantes italianos. Uma nota do Diário de Campinas condenou os abusos praticados pelos "mascates italianos" que vendiam frangos e ovos por preços "despropositados". Sua estratégia era a mesma das verdureiras: chegavam muito cedo ao mercado e arrematavam todas as aves, impedindo o público de comprar aqueles "gêneros de primeira necessidade". A nota da imprensa gerou protesto imediato - não eram apenas os italianos que exerciam aquela atividade. ${ }^{22}$

Entre as pessoas pobres que sobreviviam do comércio ambulante houve até mesmo um "preto morfético" que circulava na cidade vendendo frutas e doces, para pânico de muita gente. Havia dúvidas se era escravo ou forro mas queriam-no longe do convivio urbano, de preferência, que fosse enviado ao Asilo dos Morféticos, como solicitado à Câmara pela imprensa. O fato de a cidade possuir seu nosocômio, dedicado aos acometidos pelo "Mal de Lázaro", indica que a moléstia era comum na região e que as preocupações e práticas relacionadas à salubridade/ saúde/doença mobilizavam autoridades e opinião pública. ${ }^{23}$

A relação da Câmara Municipal com os vendedores ambulantes foi ambígua durante a segunda metade do século XIX e além, predominando uma política de cerceamento que, se de um lado procurava oferecer melhores condições de abastecimento aos habitantes da cidade, por outro, procurava controlar e limitar seus movimentos. Com as mudanças

\footnotetext{
${ }^{22}$ ACMC, 28/09/1874; Diário de Campinas, 12/12/1879, n. ${ }^{\circ}$ 1246, p. 2 .

${ }^{23}$ ACMC, 20/01/1873; Gazeta de Campinas, 15/02/1878, n. ${ }^{\circ} 1254$, p.2; Diário de Campinas, $25 / 04 / 1878$, n $^{\circ}{ }^{\circ} 758$, p.3. Sobre a atividade feminina no comércio de quitandas, tanto de escravas, forras e livres e seus constantes problemas com o fisco e posturas restritivas da câmara municipal veja o clássico trabalho de DIAS, Maria Odila Leite da Silva. Quotidiano e poder em São Paulo no século XIX. $2^{a}$ edição, São Paulo: Brasiliense, 1995. Veja também: PINTO, Maria Inez Machado Borges. Cotidiano e sobrevivência. A vida do trabalhador pobre na cidade de São Paulo, 1890-1914. São Paulo: EDUSP, 1994.
} 
urbanas, novos hábitos de consumo, decoro e civilidade se impunham, chocando-se com antigas práticas que nem sempre se rendiam facilmente diante do novo.

No início do período republicano, o Conselho de Intendentes buscou concentrar o comércio de frutas, verduras, legumes e quitandas no Mercado de Hortaliças através da resolução $n .^{\circ} 36$, proibindo terminantemente as vendas fora daquele espaço público sem a devida licença, incluindo-se ovos, peixes e aves. Assim, os ambulantes ficariam, ao menos em princípio, atrelados ao Mercado de Hortaliças e, o que era muito mais significativo, ao seu controle. Não era a primeira vez que se tentava impor a permanência dos verdureiros e quitandeiras no mercado. Na opinião do Diário de Campinas, sempre atento aos movimentos das pessoas mais pobres (o que lhe rendia farto material para suas conservadoras pautas), era importante que os ambulantes permanecessem no mercado por algum tempo, depois do qual estariam livres para percorrerem as ruas da cidade. Desse modo, tanto lucrariam os comerciantes como a população ganharia em comodidade. ${ }^{24}$

Os vendedores ambulantes de alimentos e de outros produtos eram vistos com desconfianças pelas autoridades e por uma parcela da população, especialmente quando eram negros ou imigrantes, como indicam comentários do Diário de Campinas. Os Códigos de Posturas Municipais de muitas cidades especificavam quando o comércio realizado pelos cativos era permitido. Em Campinas isso não foi diferente. Era necessária autorização do senhor e a respectiva licença paga pelo mesmo à Câmara. Com isso, os escravos tinham os mercados e as ruas da cidade para exercerem o oficio de vendedores ambulantes a serviço de seus donos. Quando os escravos viviam nas fazendas vendiam gêneros de suas roças e criações. Quando viviam na cidade, eram geralmente quitandeiros e verdureiros, alentando, raras vezes conseguindo, realizar o sonho da liberdade comprada.

\footnotetext{
${ }^{24}$ Intendência Municipal de Campinas, Resoluções relativas aos anos de 1890 a 1892, Campinas, Tip. Livro Azul, 1900, p. 9 e19; Diário de Campinas, 27/05/1890, n. ${ }^{\circ}$ 4330, p.2; Diário de Campinas, 04/06/1891, n. ${ }^{\circ} 4639$, p. 1.
} 
O comércio ambulante conferia aos escravos grande mobilidade, algo pouco conhecido pela maioria dos escravos das fazendas, com as vantagens de não ser um trabalho tão extenuante quanto o eito e de ser exercido com "o feitor ausente", o que já era um grande alívio. A escravidão no ambiente urbano ganhou um caráter mais flexível e o fato de os escravos passarem grande parte de seu tempo fora da casa e da vigilância de seu senhor, ou mesmo "vivendo sobre si", permitiu novos arranjos na relação senhor-escravo, especialmente através do "sistema de ganho". ${ }^{25}$ Em novembro de 1878, o Diário de Campinas noticiava:

Uma preta escrava andava ontem pelas ruas da cidade vendendo quitandas com a roupa ensanguentada e a cabeça ferida. Indagando-se a causa, soube-se que sua senhora, dona Carolina de tal, moradora à Rua Alegre, a espancara até ferila daquele modo por não ter ela vendido a quitanda. Algumas pessoas vizinhas informam-nos que isto já é uso e costume na casa em que serve a preta. ${ }^{26}$

Por um pouco mais flexível que fosse a escravidão urbana, ainda assim continuava a ser escravidão. A presença dos negros representava uma ameaça para muitos campineiros, cada vez mais preocupados com possiveis revoltas e com o crescimento da cidade que reunia nas praças e cortiços, brasileiros e estrangeiros de diferentes origens e condições. E o que mais sobressaltava: com intenções diversas, quase sempre tidas como suspeitas e reprováveis. O aumento da

\footnotetext{
${ }^{25}$ ALGRANTI, Leila Mezan. O feitor ausente. Petrópolis: Vozes, 1988, p. 47, 49 e 58. Os escravos de ganho saíam às ruas procurando trabalho e prestavam serviços mediante remuneração, entregando ao senhor uma quantia em dinheiro previamente estabelecida em acordo entre ambos. Segundo Leila Algranti, o sistema de ganho constituiu uma peculiaridade da escravidão urbana. Sobre o escravo "vivendo sobre si", Chalhoub demonstra que, para o caso da Corte, esse "afrouxamento" do domínio dos senhores sobre seus escravos resultou em uma adaptação da escravidão urbana aos desígnios do mercado. Por outro lado, indaga o autor, não seriam essas transformações ocorridas na relação senhor-escravo no meio urbano uma construção dos próprios escravos, na medida em que, ao viverem sobre si, cada vez mais se diluíam as distinções entre os livres pobres e os escravos? Veja: CHALHOUB, Sidney. Visões da liberdade. São Paulo: Companhia das Letras, 1998, p. 215-216.

${ }^{26}$ Diário de Campinas, 10/11/1878, n. ${ }^{\circ} 918$, p.1.
} 
população gerou riquezas e também problemas, públicos e privados, alguns deles passionais.

Em 1883, o quitandeiro Antonio Nunes Reis, "há tempos que arrastava a asa a uma mulher amasiada com Sebastião Vicente de Morais, trocando-se entre os dois correspondência ativa". Eis que Sebastião descobriu "as tramas da pérfida e do Nunes" e resolveu tirar satisfações de seu rival. A oportunidade logo se apresentou. Nunes vendia suas quitandas na Rua das Flores quando se viu diante de um homem tomado pela cólera do ciúme:

Vê-lo e precipitar-se contra ele foi obra de um instante. O tabuleiro da quitanda voou da cabeça de Nunes que ficou circundado por uma chuva de doces. Esta chuva foi para o infeliz Nunes preliminar de amarga borrasca. Com efeito, logo Sebastião lhe caiu com tal fúria de pontapés e bofetões que o pobre Nunes não dava mais acordo de si. ${ }^{27}$

Populares tomaram a defesa da parte fraca e, com a chegada da polícia, Sebastião foi conduzido à cadeia para esfriar um pouco a cabeça.

Cotidianamente, a vida dos vendedores ambulantes se complicava com as exigências que cresciam com a cidade. A partir do Código de Posturas Municipais de 1876, para conduzir uma carroça levando mercadorias ou passageiros era obrigatório ter habilitação. Para obtê-la, o candidato a cocheiro precisava matricular-se na polícia e ser submetido a um exame que comprovaria sua habilidade para conduzir carroças. Uma vez aprovado, o candidato deveria atestar também sua idoneidade moral. Cumpridos esses pré-requisitos, mais que meras formalidades, era necessário pagar licença anual à Câmara Municipal. As regras para organizar e disciplinar o trânsito nas ruas começavam a ser esboçadas a partir de então e, em poucos anos, mão e contramão passaram a orientar os veículos.

Em uma preguiçosa manhã de domingo de 1908, Domingos Francisco foi multado pelo fiscal municipal em

${ }^{27}$ Diário de Campinas, 28/11/1883, n. ${ }^{\circ}$ 2400, p.2. 
$10 \$ 000$ réis por trafegar com sua carroça de pão na contramão. ${ }^{28}$

Se verdureiros, quitandeiras e padeiros sobre rodas tinham seus problemas com as novas regras de circulação viária na cidade que se transformava, seus companheiros que trabalhavam a pé, com tabuleiros ou cestos também tinham os seus. A Câmara Municipal passou a regular cada vez mais detalhadamente o uso e a ocupação do espaço urbano, inclusive no que dizia respeito à circulação de pessoas e mercadorias. Uma nova e idealizada maneira de ver e se relacionar com a cidade chocou-se inúmeras vezes com uma realidade ainda repleta de antigas práticas.

O trabalho dos verdureiros, quitandeiras, leiteiros, peixeiros e tripeiros era útil à população, mas, para urbanistas e sanitaristas, o comércio ambulante era visto como obstáculo da livre circulação e que, muitas vezes, comprometia a salubridade urbana. A busca burguesa da cidade ideal, bela e higiênica incluía a boa qualidade dos alimentos, requisito indispensável para garantir a saúde e a produtividade da força de trabalho.

A gestão dos problemas relacionados ao abastecimento das cidades passou a integrar a esfera da saúde pública, que começava a desenvolver um discurso e uma prática apoiados em pressupostos científicos. A estas questões juntava-se outra mais sutil: a maneira de ser irreverente da gente pobre que lutava pela vida apregoando suas mercadorias - pelas ruas, de porta em porta. Seu linguajar, gestos e atitudes feriam os novos padrões de decoro e convivio social que, aos poucos, se impunham na cada vez mais aburguesada Campinas do café.

Uma negra vendedora de ovos e quitandas, dona de uma voz poderosa, percorria a cidade com sua mercadoria em uma manhã de setembro de 1885. Após realizar algu-

\footnotetext{
${ }^{28}$ Commercio de Campinas, 07/01/1908, n. ${ }^{\circ} 2218$, p.2. Sobre a exigência de habilitação para conduzir carros e as demais obrigações e prescrições : Lei n. ${ }^{\circ}$ 44 - Câmara Municipal de Campinas, Leis, resoluções etc de 1895, Campinas: Tip. Livro Azul, 1895, p.23 a 28. Regras muito rígidas impostas aos cocheiros pela policia, motivaram greves em 1883, 1885 e 1891 .
} 
mas vendas, passou a enfrentar problemas com seus fregueses. Muitos dos ovos que vendera estavam podres e, quando questionada sobre o assunto, desandava a proferir os mais cabeludos impropérios. Naquele mesmo ano, o filho de um comerciante de frangos no Mercado Grande foi promovido por seu pai e patrão a vendedor de frangos ambulante. Mais uma vez, os consumidores ficaram no prejuízo. Constatouse que os galináceos vendidos pelo rapaz eram "pesteados, conseguindo iludir a boa fé de várias pessoas, que só depois de comprado o gênero reconhecem o logro". ${ }^{29}$

Entre os alimentos de consumo diário distribuídos pelos vendedores ambulantes, muitos dos quais eram pequenos criadores que viviam em chácaras e sítios nos arredores da cidade, o leite era um dos que mais acumulavam problemas e reclamações. Antes do nascer do sol, muitos deles já percorriam as ruas conduzindo suas vacas que eram ordenhadas diante do freguês, não deixando dúvidas quanto à pureza do produto. Essa prática, no entanto, não era regra e, com o crescimento da cidade e do consumo de leite, o cortejo matutino das bovinas e o badalar de seus sinos foi rareando. Por praticidade e maior capacidade de armazenamento, muitos produtores de leite passaram a distribuí-lo em latas, sobre carroças ou lombo de burro. Como acontecia com outros gêneros alimentícios, o leite também era comprado diretamente dos produtores para ser revendido. Assim, como muitos verdureiros, muitos leiteiros das manhãs campineiras não produziam o que vendiam.

O leite transportado em latas, vendido aos litros e canecas, muitas vezes, era bem diferente daquele que jorrava do úbere das vacas. A adulteração era constante. Misturá-lo com água era a mais comum das artimanhas entre os ambulantes que procuravam aumentar seus rendimentos. Quem não comprasse dos tradicionais leiteiros que tiravam o leite na hora da venda ou não possuísse sua própria vaca, estava sujeito a consumir um leite bastante "aguado".

${ }^{29}$ Gazeta de Campinas, 04/09/1885, n. ${ }^{\circ} 3484$, p.2; Correio de Campinas, 21/11/1885, n. ${ }^{\circ} 266$, p. 1 . 
As reclamações quanto àquela prática abusiva e que poderia trazer prejuízos à saúde pública eram comuns, sem alterar, contudo, o estado das coisas. Para combater a ação dos leiteiros inescrupulosos e garantir a boa qualidade do leite das crianças, o vereador Ricardo Gumbleton Daunt indicou, em outubro de 1884, que a Câmara adquirisse um lactômetro. Com o uso daquele instrumento, os fiscais poderiam facilmente detectar a presença de água em excesso no leite e punir os infratores. O lactômetro causou seus impactos:

Exame de leite - Anteontem, os srs. fiscais procederam no mercadinho ao exame do leite destinado à venda ao público, servindo-se para isso do instrumento lactômetro, mandado vir pela câmara por indicação do Sr. Dr. Ricardo Daunt. Consta que alguns dos vendedores de leite não puro, quando souberam desse exame puseram-se ao fresco, por suporem que o traziam misturado com água. ${ }^{30}$

Como a tecnologia e os homens têm seus limites, muito do leite vendido na cidade continuou a apresentar problemas. Em setembro de 1885, o leiteiro José Ferreira da Costa oficiou à Câmara Municipal pedindo isenção de uma multa recebida por vender leite com água. Em seu arrazoado, Costa justificava que o leite considerado adulterado pelos fiscais era puro. Ocorreu que o leite examinado havia sido tirado de novilhas com crias novas e que, nesses casos, "o leite parece ter água por pouco espesso". Acrescentava o peticionário que não convinha desacreditar seu negócio e sujeitar-se a uma multa mais pesada que o lucro que poderia auferir. Geralmente, pedidos dessa natureza eram ignorados pela Câmara. ${ }^{31}$

As denúncias contra os ambulantes que vendiam leite "batizado", muitas vezes com água de "córregos imundos", continuaram movimentando a imprensa, a população e os vereadores nos anos seguintes. ${ }^{32}$

\footnotetext{
${ }^{30}$ ACMC, 20/10/1884; Gazeta de Campinas, 18/11/1884, n. ${ }^{\circ} 3244$, p.2.

${ }^{31}$ ACMC, 21/09/1885.

${ }^{32}$ Gazeta de Campinas, 07/08/1887, n. ${ }^{\circ}$ 4056, p.1; Correio de Campinas, $27 / 08 / 1887$, n. $^{\circ} 790$, p. 2. 
Fiscalizar o leite em toda a cidade era tarefa dificil. Os leiteiros eram exímios em fugir dos fiscais e seus perigosos lactômetros. Como o número de leiteiros era grande, entre legais e clandestinos, e a venda do leite ocorria principalmente pela manhã, muitos deles acabavam sem ter seu produto submetido ao comprometedor exame de pureza. Essas dificuldades na fiscalização foram percebidas pela população e também pela casa comercial de Santos, Irmão \& Nogueira, que aproveitou para aumentar seu faturamento. Em 1898, a casa anunciava nos jornais a venda do "pesa-leite - instrumento para verificação da qualidade do leite". Certamente, essa foi uma notícia ruim para muitos leiteiros, mas festejada pelos consumidores. ${ }^{33}$

Outro motivo de reclamações generalizadas era a venda de miúdos e tripas de boi e porco, de consumo bastante difundido. O comércio daqueles alimentos era realizado principalmente pelos tripeiros ambulantes e, segundo os fiscais das freguesias da Conceição e Santa Cruz, em 1902, as carroças utilizadas por eles "não têm as precisas condições porquanto não são cobertas e expõem aos raios do sol as mercadorias que conduzem que se deterioram com grave perigo para a saúde pública". Os fiscais solicitavam que a Intendência Municipal ordenasse a imediata reforma das carroças dos tripeiros, "de modo a cessar o inconveniente apontado". ${ }^{34}$

Os resultados de tal solicitação foram limitados. Em 1906, o tripeiro José Discola, depois de multado por vender miúdos deteriorados e ter seus corações, buchos e bofes apreendidos pelo fiscal, protestou contra o fato, afirmando que os miúdos apreendidos estavam "naturalmente um pouco estragados", devido ao calor no dia da apreensão. ${ }^{35}$

Em Campinas, de maneira semelhante a São Paulo, à medida que o século XIX terminava, iniciou-se um "conflito histórico, jamais resolvido, entre a apropriação da rua como

\footnotetext{
${ }^{33}$ APHC, cx. 1902/01, pasta fevereiro, 18/02/1902; Cidade de Campinas, 29/11/1904, n. ${ }^{\circ} 1123$, p.2; Diário de Campinas, 05/02/1898, n. ${ }^{\circ} 6567$, p.3. Pesa-leite era outro termo que denominava o lactômetro.

${ }^{34}$ APHC, cx. 1902/01, pasta fevereiro, 03/02/1902.

${ }^{35}$ APHC, cx. 1906/02, pasta junho, 25/04/1906.
} 
espaço de circulação e todos os demais usos, automaticamente excluídos. O conflito teve uma primeira manifestação no expurgo da atividade de quitanda". ${ }^{36}$

Em 1877, as queixas contra a presença dos tabuleiros de quitandeiras e outros vendedores nas calçadas foram constantes. O Código de Posturas do ano anterior, em seu artigo 115, determinava que: "É permitido vender pelas ruas da cidade frutas, aves, peixes e outros gêneros propriamente chamados - de quitanda. Os vendedores não poderão, porém, permanecer nas ruas e lugares públicos fora do mercado respectivo. Os infratores serão multados de $5 \$ 000$ a $10 \$ 000$ réis, e em 2 dias de cadeia não tendo com que pagar". Fica claro nessa postura o desejo da Câmara em restringir a permanência dos ambulantes nas ruas e demais lugares públicos, buscando concentrá-los no espaço do Mercado de Hortaliças - público, porém delimitado, regido por um regulamento, vigiado pelo inspetor e, comumente, devassado pela polícia. Quanto àqueles apanhados pelos fiscais nas ruas, certamente não foram poucos os que passaram dois dias na cadeia.

Entre as regras que as autoridades municipais esperavam que fossem cumpridas e o que ocorria de fato, havia certo descompasso. Os ambulantes estavam em toda parte, sempre se esquivando dos fiscais, suas normas e multas. Essas tensões do dia-a-dia já haviam sido mais amenas quando a cidade era menor, e a vida, aparentemente mais simples. As novas regras e preocupações quanto à vida nas cidades por parte de políticos e médicos, além do crescimento populacional, pressionaram ainda mais as restritas oportunidades de trabalho livre. Ajustes entre novos e antigos hábitos e práticas tornaram-se comuns, nem sempre ocorrendo de maneira tranquila e cordata. O Código de Posturas de 1880 deixou as preocupações da Câmara quanto aos problemas de circulação urbana ainda mais explícitas. É o que se pode notar em seu artigo 78, variação do artigo 115 do código de 1876:

${ }^{36}$ ROLNIK, Raquel. A cidade e a lei. São Paulo: Studio Nobel/FAPESP, 1997, p. 31-32. 
Os gêneros chamados de quitanda, como frutas, aves, peixes e outros serão vendidos no respectivo mercado. Os negociantes de gêneros acima especificados podem igualmente vendêlos pelas ruas da cidade, contanto que os vendedores não estacionem, senão nos lugares indicados. Os que venderem doce em tabuleiros poderão estacionar pelas ruas, contanto que não embaracem o trânsito.

Mesmo com tais dificuldades, os ambulantes circulavam por toda cidade, mas tinham grande predileção pelos movimentados passeios próximos ao cruzamento da Rua General Osório com Rua do Comércio. Ali permaneciam com seus tabuleiros em frente a várias casas comerciais e açougues, para desespero de seus proprietários. Sujavam o lugar com cascas de frutas, restos de verduras e atrapalhavam o livre acesso de mercadorias e fregueses a seus estabelecimentos. Essa era, pelo menos, a versão dos comerciantes. ${ }^{37}$

A Rua do Comércio era um conhecido reduto dos verdureiros e quitandeiras que remontava aos primórdios das "casinhas", e que a Câmara tratou de "desimpedir" transferindo aqueles precários comerciantes para o recinto fechado do primeiro Mercado de Hortaliças, inaugurado em 1872. ${ }^{38}$ Mas, aos poucos, os ambulantes foram retomando aquele tradicional e estratégico ponto comercial. Afinal, a licença para vender no Mercadinho era muito cara para comerciantes pobres, e nem todos podiam ou estavam dispostos a pagá-la.

Alguém que se dizia "Um Justiceiro" protestava que os quitandeiros não apenas "vedam o trânsito público pelos passeios, como também deixam imundos os lugares onde estacionam e, frequentemente, já se têm originado dúvidas

\footnotetext{
${ }^{37}$ Gazeta de Campinas, 02/02/1877, n. ${ }^{\circ}$ 953, p.2. A antiga Rua do Comércio é a atual Rua Dr. Quirino. A Atual Rua General Osório era a antiga Rua das Casinhas.

${ }^{38}$ As "casinhas" foram inauguradas em 1819. Era um recinto coberto e fechado, dividido em compartimentos para comércio de carnes verdes e cereais. Pessoas que tinham hortas em seus sitios, chácaras e quintais comercializavam verduras e legumes junto àquele edificio, ao ar livre. A presença daquele lugar de comércio deu nome à rua onde se localizava: Rua das Casinhas.
} 
e questões entre quitandeiros por causa da colocação dos tabuleiros". ${ }^{39}$

Utilizando um discurso que defendia a livre circulação, higiene e ordem, o "Justiceiro" expressava o descontentamento de uma parcela significativa de campineiros, preocupados com tudo que, de alguma forma atravancava o trânsito, sujava e provocava tumultos em uma cidade cada vez maior e mais rica, e que se desejava culta e civilizada. Nem mesmo os fiscais com seu poder para multar conseguiam que os indomáveis quitandeiros cumprissem as posturas municipais.

Em oficio à Câmara, o fiscal da Freguesia da Conceição, Juvêncio Fernandes de Oliveira, informava um tanto desanimado que os quitandeiros insistiam em estacionar em frente aos açougues na Rua do Comércio:

Aglomerando-se em grande número de forma a trazer graves inconvenientes e prejuízos aos transeuntes, em virtude do grande ajuntamento de pessoas quer sobre os passeios quer no centro da rua, aí se conservam até venderem totalmente toda a quitanda, apesar das reiteradas intimações para não estacionarem em parte alguma a não ser no mercadinho de verduras, podendo apenas parar para unicamente servirem seus fregueses. Acontece, entretanto, não obedecerem às intimações que lhes são feitas em manifesto desrespeito à lei. E sendo já a quarta vez que assim procedo, mandei apreender os ditos carrinhos e mais carroças ali encontradas em ajuntamento, multando-os em $5 \$ 000$ réis cada um para obrigá-los ao cumprimento da lei, na forma do Regulamento do Mercadinho, pois pelo Código de Posturas é de $10 \$ 000$ réis a importância da multa (...) muitos pagaram prontamente sem a mínima reclamação por conhecerem a legalidade das mesmas multas. ${ }^{40}$

Neste caso, os quitandeiros encontraram um fiscal camarada porque não apenas adiou ao máximo as multas e apreensões como ainda aplicou a multa menos pesada possível aos resistentes comerciantes das ruas. Apesar das proibi-

${ }^{39}$ Diário de Campinas, 09/04/1884, n. ${ }^{\circ}$ 2508, p.3; ACMC, 21/04/1884.

${ }^{40}$ Arquivo da Câmara Municipal de Campinas Arq.CMC, cx. E1/5, pasta 1888/ III, 25/02/1888. 
ções por parte das posturas municipais, da fiscalização e das reclamações constantes, os verdureiros e quitandeiras continuaram a trabalhar naquele local e arredores. Ser multado ou ter a mercadoria apreendida era um risco que valia a pena correr. Afinal, a Rua do Comércio não tinha aquele nome por acaso. O ponto era dos melhores desde as décadas iniciais do século XIX. Ali a cidade passava, ali havia fregueses.

Outro lugar de unânime preferência entre os quitandeiros para realizarem suas vendas e que também gerou controvérsias foi o Largo da Estação. A chegada da ferrovia a Campinas permitiu o escoamento das safras de café diretamente ao porto de Santos com rapidez e economia. A mesma ferrovia, que levava o café serra abaixo, trazia produtos importados para seletos consumidores enriquecidos com o "ouro verde". Os trens facilitaram o fluxo de imigrantes que se dirigiam às fazendas do interior e, com suas cargas, passageiros e linhas telegráficas, encurtaram distâncias entre o planalto paulista, o mundo e suas novidades. A estação da Companhia Paulista, à qual se juntaria a Companhia Mogiana de Estradas de Ferro, localizou-se nos limites da área urbana. A partir de então, a cidade começou a crescer para além da ferrovia, ocupando territórios até então destinados àquilo que se desejava distante por questões higiênicas e estéticas: Matadouro Municipal, Asilo dos Morféticos e alguns antigos cemitérios como o dos "Acatólicos", que acabaram sendo desativados e os ossos, transferidos para o novo Cemitério do Fundão, dando passagem aos vivos e ao desenvolvimento.

Nas proximidades da estação, instalaram-se algumas indústrias que se utilizavam da ferrovia para receber matérias primas e escoar sua produção. Seus operários, juntamente com os ferroviários, constituíram a maior parte dos moradores da Vila Industrial, um novo bairro surgido além da estrada de ferro em finais do século XIX. O Largo da Estação tornou-se local de intensa circulação de pessoas e mercadorias, de comércio e da própria vida social da cidade. Ali os ambulantes dispunham de variados possiveis fregueses: viajantes chegando ou partindo de trem, operários das fábri- 
cas e transeuntes. Seu pequeno e sortido comércio a retalho satisfazia necessidades de consumo popular e imediato, mas havia aqueles que não se entusiasmavam nem um pouco com sua nada discreta presença.

Em dezembro de 1889, o vereador Salvador Leite de Camargo Penteado informava seus colegas camaristas que os ambulantes "fazem [no Largo da Estação] despejos de resíduos prejudiciais à saúde pública, e mais, que esses indivíduos, além de impedirem o trânsito, em constantes altercações proferem palavras obscenas, não prestando o devido respeito às famílias e mais pessoas que ali vão tomar o bonde, chegando mesmo ao desforço pessoal entre si". Penteado sugeriu a interdição daquele local aos comerciantes ambulantes requisitando o auxílio da polícia, caso necessário, para cumprir aquela determinação, "visto tratar-se de assunto de boa ordem e do bem público". ${ }^{41}$

A sugestão de Penteado foi aprovada mas a "ordem pública" continuou comprometida, para desagrado dos comerciantes que se diziam lesados. Para os profissionais das ruas, o Largo da Estação era um ótimo lugar para os negócios. ${ }^{42}$

As controvérsias com o poder público e comerciantes de maior porte pelo espaço da cidade para exercerem seu humilde e necessário ofício eram constantes. Outra dificuldade que afligia os ambulantes era a licença exigida pela Câmara Municipal a fim de trabalharem legalmente. Por pobreza ou opção, muitos deixavam de pagá-la e levavam cada dia no fio da navalha. Até que, cedo ou tarde, deparavamse com o fiscal e, ou pagavam a licença imediatamente ou eram multados, além de terem sua mercadoria apreendida. Aquela prática era uma forma de resistir ao fisco o quanto possível, uma vez que viviam a incerteza cotidiana de conseguir sua subsistência e de suas famílias. Por outro lado, muitos ambulantes que pagavam suas licenças em janeiro, quando a Câmara recolhia seus impostos à "boca do cofre",

\footnotetext{
${ }^{41}$ ACMC, 09/12/1889.

${ }^{42}$ Arquivo Público e Histórico de Campinas, cx. 1905/03, pasta agosto, 12/08/1905; APHC, cx. 1905/03, pasta agosto, 17/08/1905. 
sentiam-se prejudicados pela concorrência dos que optavam por "arriscar a sorte", não hesitando em denunciá-los aos fiscais até mesmo pela imprensa, para defender seus direitos literalmente adquiridos: "Aos srs. Fiscais - Prevenimos a VV SS. que há nesta cidade grande quantidade de tabuleiros de carne mercando pelas ruas que não pagam os direitos; o que esperamos é VV SS. darem as devidas providências necessárias. Ass. O espião". ${ }^{43}$

$\mathrm{Na}$ árdua luta pela sobrevivência em uma sociedade escravista, e que depois da abolição excluiu grande parte de sua população do mercado de trabalho, especialmente os ex-escravos e seus descendentes, era comum ocorrerem divisões entre os próprios trabalhadores pobres, entre os quais se destacavam os ambulantes. Disputas pelos melhores "pontos", pela preferência dos fregueses, a concorrência entre vendedores do mesmo produto e rixas pessoais, pontuavam os dias de homens e mulheres que faziam das ruas seu lugar de trabalho e sociabilidade. Com o crescimento da cidade e suas transformações, alguns deles se adaptavam mais rapidamente e melhor que outros, engrossando, de certa maneira, o combate aos transgressores dos novos padrões de vivência urbana que se consolidavam.

Na passagem do século XIX ao XX, os fiscais apertaram o cerco contra os ambulantes. Em 1899, Leopoldo Amaral registrou 294 quitandeiros (vendedores de frutas, doces, legumes e aves); 69 leiteiros e 29 vendedores de carnes verdes em tabuleiros, entre outros tantos ambulantes como latoeiros, engraxates, vendedores de lenha, roupas feitas, armarinhos, amoladores de facas e tesouras, sapateiros e ferreiros. Amaral mencionou os legalizados porque muitos trabalhavam clandestinamente sem pagar a obrigatória e abominada licença à Câmara. ${ }^{44}$

As preocupações com a salubridade urbana e a saúde pública estavam em evidência em função das epidemias de

${ }^{43}$ Diário de Campinas, 22/05/1883, n. ${ }^{\circ} 2245$, p.2.

${ }^{44}$ AMARAL, Leopoldo. A cidade de Campinas em 1900. Campinas: Tip. Livro Azul, 1899 , p. 359. 
febre amarela que castigaram Campinas na década de 1890. A grande mortalidade causada por uma doença considerada típica do litoral gerou apreensões nas autoridades quando atingiu o interior paulista, onde se localizavam as grandes fazendas de café.

Temia-se que a febre amarela e as más condições sanitárias constituíssem um entrave às correntes imigratórias, que acabariam desviadas de São Paulo para outros países que disputavam com o Brasil mão-de-obra e povoadores. O saneamento de Campinas, Santos e de outras cidades interioranas era imprescindivel para uma boa propaganda de São Paulo no exterior, carente de braços para seus cafezais e sua indústria nascente. Tais temores motivaram a intervenção do Serviço Sanitário Estadual. Em 1896, chegou a Campinas uma Comissão Sanitária, chefiada pelo Dr. Emílio Ribas, sucedido pelo Dr. Theodoro Bayma. Com grandes poderes, a Comissão Sanitária promoveu inúmeras intervenções a fim de livrar a cidade do "mal do vômito preto" . Naquele período, o sanitarista Saturnino de Brito também trabalhou em Campinas, sendo responsável, entre outras obras importantes, pela construção do "canal do saneamento", que recolheria grande parte dos esgotos urbanos. ${ }^{45}$

A convivência com as ações e discursos dos médicos e seus agentes durante e após as epidemias acentuou em todos, em diferentes intensidades, a ideia de que salubridade/ higiene é igual à saúde e vida. Essa atitude defensiva diante do que poderia ameaçar a saúde pública por certo contribuiu para que os fiscais fechassem o cerco aos vendedores ambulantes, especialmente aqueles que vendiam alimentos. Em suas correições, os fiscais realizavam vistorias, cobranças e

\footnotetext{
${ }^{45}$ SANTOS FILHO, Lycurgo de Castro e NOVAES, José Nogueira. A febre amarela em Campinas, 1889/1900. Campinas: Publicações CMU/UNICAMP, 1996. Veja também: ANDRADE, Carlos Roberto Monteiro de. Projetos e obras de Saturnino de Brito para Campinas em finais do século XIX. Oculum. Campinas: número 2, p. 10-23, jan. 2002. Ainda sobre a febre amarela veja: BENCHIMOL, Jaime Larry. Febre amarela: a doença e a vacina, uma história inacabada. Rio de Janeiro: Fiocruz, 2001.
} 
apreensões em plena via pública, o que, não poucas vezes, gerava conflitos. ${ }^{46}$

Os pagamentos das licenças em situações como aquelas nem sempre eram muito amistosos e causavam constrangimentos para ambulantes e fiscais. Além das reclamações de praxe, os ânimos podiam se exaltar. As coisas podiam ser resolvidas com alguma diplomacia, mas havia casos em que a polícia intervinha porque a integridade fisica do fiscal era ameaçada. Em 28 de novembro de 1901, os fiscais José Falque e Virgilio Bittencourt faziam seu trabalho percorrendo a cidade. Na esquina das ruas Saldanha Marinho com Barreto Leme, encontraram o vendedor ambulante de carne Angelo Patera e lhe pediram que apresentasse sua licença e o número de seu tabuleiro. Como se recusasse a atendê-los, apreenderam a mercadoria recolhendo-a na casa de Álvaro Grillo, morador nas imediações. Horas depois, bastante nervoso, Patera encontrou-se com os fiscais no mesmo local da apreensão, exigindo sua carne de volta. Falque e Bittencourt disseram que para isso seria obrigatório o pagamento dos impostos devidos. Inconformado e cada vez mais inflamado, o italiano passou a insultar e desafiar os fiscais. No auge de sua ira, puxou um revólver e ameaçou Bittencourt que tentou agarrá-lo. O ambulante fugiu pela Rua Campos Sales, sendo capturado por policiais a pedido dos fiscais. Bittencourt e Falque apresentaram queixa ao delegado contra Patera que permaneceu no xadrez. ${ }^{47}$

Encontros dos ambulantes com fiscais mais exaltados e prepotentes também ocorriam. Em 1878, um cidadão que ocupava interinamente o cargo de fiscal deixou o poder subir-lhe à cabeça. Dizia a imprensa que o homem costumava andar armado com uma garrucha e tinha como cetro de sua autoridade um chicote. Com aqueles argumentos, sem dúvida persuasivos, o severo fiscal procurava fazer cumprir

${ }^{46}$ Sobre a ação dos fiscais e apreensões veja: APHC, cx. 1902/01, pasta fevereiro, 15/02/1902; APHC, cx. 1903/01, pasta fevereiro, 04/02/1903; APHC, cx. 1903/02, pasta maio, 18/05/1903; APHC, cx. 1904/01, pasta fevereiro, $02 / 02 / 1904$.

${ }^{47}$ APHC, cx. 1901/02, pasta novembro, 28/11/1901. 
as posturas municipais. Na noite de 31 de março daquele ano, uma escrava estava com seu tabuleiro de doces na Rua General Osório. Para sua infelicidade, ali passou o tal fiscal interino:

Vê-la e atirar uma relhada ao tabuleiro fazendo voar os doces e o lampião do mesmo foi obra que nem mesmo o diabo era capaz de fazer em menos tempo; e não satisfeito com isto, o Senhor Fiscal soltou-lhe a lingua e disse-lhe coisas feissimas! À vista disto é forçoso reconhecer que este empregado público está muito nos casos de assinar um termo de bem viver. $^{48}$

Apesar da indignação de quem relatou o ocorrido, nada aconteceu ao fiscal que, bastava ver um quitandeiro parar ao atender um pedido, para dizer: "caminha! caminha!".

A imprensa, que tantas vezes criticava a atuação dos ambulantes, também condenava abusos praticados por funcionários municipais. Neste caso, o Diário de Campinas foi bastante incisivo ao sugerir que o fiscal assinasse um termo de bem viver, fato que não motivou nenhuma providência por parte da Câmara Municipal.

Os fiscais podiam usar sua posição para tirar algum proveito próprio, o que colaborou muitas vezes para desmoralizar a função que exerciam. Na manhã de 2 de fevereiro de 1902, próximo à estação ferroviária, um ambulante teve sua carne de carneiro apreendida pelo fiscal do Distrito da Conceição, Antonio Benedito de Oliveira Ferraz. Ao ser abordado pelo fiscal, o comerciante admitiu que o animal não havia sido abatido no Matadouro Municipal, o que era expressamente proibido pelas posturas. Depois de multar o infrator, Ferraz depositou a carne apreendida no Corpo de Bombeiros. Sem carneiro e sem dinheiro, o ambulante autuado caminhava para espairecer quando, por volta das 10 horas, deparou-se com o fiscal do Distrito de Santa Cruz,

\footnotetext{
48 Diário de Campinas, 02/04/1878, n. ${ }^{\circ}$ 741, p.2; Diário de Campinas, 07/04/1878, n. ${ }^{\circ}$ 746, p.1. Termo de Bem Viver era um documento assinado diante das autoridades policiais por uma pessoa presa ou acusada por vadiagem, comprometendo-se a trabalhar dentro de um prazo estabelecido. O não cumprimento desse compromisso poderia acarretar em prisão.
} 
José Falque, em frente à Matriz da Conceição. Notou então que o apressado Falque conduzia um embrulho, do qual sobressaia claramente uma perna de carneiro que lhe pareceu familiar. Apurou-se depois que Falque havia passado pelo Corpo de Bombeiros e retirado para si um pedaço da carne apreendida por seu colega Ferraz. Houve denúncia do fato e, depois de informar-se sobre o ocorrido, o vereador Antonio Álvares Lobo concluiu que Falque não deveria ter levado para casa mercadoria apreendida. E caso encerrado. ${ }^{49}$

Contratempos do ofício à parte, os vendedores ambulantes não contribuíam apenas para dinamizar o abastecimento urbano, prestando assim um grande serviço à população. Eles representavam também uma importante fonte de arrecadação para o município que crescia e muitas vezes se endividava. Em outubro de 1906, o vice-presidente da Câmara, Artur Leite de Barros, apresentou um projeto de lei para realização de um empréstimo de 3.200:000\$000 réis (três mil e duzentos contos de réis), para ser aplicado no resgate de títulos da dívida ativa consolidada, "vencida e por vencer". O prazo máximo para o pagamento daquela fábula seria de 50 anos e, como garantia dos serviços de juros e amortização, sugeria que a Câmara empenhasse a totalidade da arrecadação dos impostos denominados "indústrias e profissões, ambulantes e veículos, ou outros que forem acertados caso aqueles não sejam julgados suficientes". Pelo projeto, a Câmara estaria impedida de contrair novo empréstimo até amortizar pelo menos a metade do total emprestado. Não importa se o empréstimo foi realizado e em que condições. Importa saber que mesmo a atividade de humildes vendedores ambulantes, através das licenças que pagavam, poderia ajudar a garantir um empréstimo vultoso. ${ }^{50}$

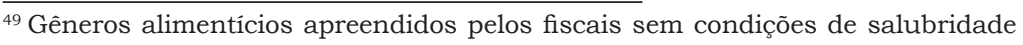
eram (ou deveriam ser) inutilizados, enquanto as mercadorias não reclamadas, mas em boas condições para o consumo, geralmente seguiam para os hospitais da cidade. Veja: APHC, cx. 1902/01, pasta fevereiro, 03, 04, e 08/02/1902. Situações de conflito entre a fiscalização e vendedores ambulantes no Rio de Janeiro podem ser conferidas em: SILVA, Eduardo. As queixas do povo. Rio de Janeiro: Paz e Terra, 1988, p. 136-140.

${ }^{50}$ ACMC, 20/10/1906; ACMC, 22/10/1906.
} 
Verdureiros e quitandeiras, com seus cestos e tabuleiros, gestos e maneiras, acuados pelas transformações da cidade ainda circulariam por muito tempo em Campinas. Afinal, seus fregueses não mudavam de hábitos tão facilmente, preferindo comprar o que precisavam na porta de suas casas ou pelas ruas, com a vantagem de saber as novidades e tirar um dedo de prosa. As mudanças dos costumes são lentas e parciais, demandam acomodações variadas e um quebracabeça de perdas e ganhos que só o tempo define. ${ }^{51}$

\section{Pelas ruas, de porta em porta. Verdureiros, quitandeiras e o comércio ambulante de alimentos em Campinas na passagem do Império à República}

Valter Martins

Resumo: O artigo analisa aspectos do comércio ambulante de alimentos na cidade de Campinas nas últimas décadas do século XIX e início do XX. Discute como as mudanças urbanas naquele período atingiram o cotidiano dos envolvidos com o abastecimento. Verdureiros e quitandeiras tinham dificuldades em seus encontros com os fiscais e com as restrições das Posturas Municipais ao seu trabalho e ao seu modo de ser enquanto uma nova urbanidade aos poucos se consolidava.

Palavras-chave: vendedores ambulantes; comércio de alimentos; transformações urbanas; Campinas.

Abstract: This article analyses aspects of the food trade carried through by the ambulant salesmen in the city of Campinas in the last few decades of XIXth century and beginning of the XXth. One search to argue how the urban changes in that period reached the daily life of those people

\footnotetext{
${ }^{51}$ THOMPSON, Edward P. Costumes em comum. São Paulo: Companhia das Letras, 1998, p.150-202. 
Pelas ruas, de porta em porta.

involved with the supplying. "Verdureiros" and "quitandeiras" shared the problems faced in the meeting with the inspectors and the restrictions of the Municipal Positions with regard to their work and way of being, while new norms of urbanity were consolidated.

Keywords: ambulant salesmen; food trade; urban changes; Campinas.

Artigo recebido para publicação em 19/11/2009

Artigo aprovado para publicação em 10/12/2009 